\title{
Biblioteki i bibliotekarze partyjni w województwie warszawskim w latach 1949-1954 w świetle dokumentów Komitetu Centralnego PPR oraz Warszawskiego Komitetu Wojewódzkiego PZPR
}

Biblioteki i czytelnictwo były dla komunistów ważnymi elementami działań mających na celu wychowanie „człowieka socjalizmu”. Stąd skupienie uwagi władz na organizacji sieci bibliotek i ruchu wydawniczym. Dekret z 1946 r. powierzał utrzymanie bibliotek państwu, a powołanie wojewódzkich, powiatowych i gminnych społecznych komitetów bibliotecznych, o charakterze doradczym odpowiednim radom narodowym ${ }^{1}$. W większości komitety te ${ }^{2}$, tak jak i późniejsze Rady Czytelnictwa i Książki³, pozostały „fasadowe”, do czego przyczynił się po części brak zainteresowania inicjatywą ze strony działaczy partyjnych, szczególnie na poziomie gmin. Również część powstałych w 1948 r. bibliotek gminnych i punktów bibliotecznych była „martwa”, na co wpływ miała m.in. właśnie postawa lokalnych działaczy partyjnych i ich obojętny stosunek do bibliotek i rozwoju czytelnictwa, co przekładało się na wiele doraźnych i pozornych działań władz w tym zakresie, szczególnie podczas dorocznych obchodów Dni Oświaty, Książki i Prasy czy przy organizacji konkursów czytelników wiejskich, gdy lokalne rady musiały wykazać się przekroczeniem planu w sprawozdaniach ${ }^{4}$.

1 Dekret z dnia 17 kwietnia 1946 r. o bibliotekach i opiece nad zbiorami bibliotecznymi, Dz. U. R. P. 1946, nr 26, poz. 163.

2 Oficjalnie komitety biblioteczne zlikwidowano w 1953 r. (Uchwała Rady Ministrów nr 695 z dnia 24 września 1953 r. w sprawie zniesienia Komitetów bibliotecznych. Monitor Polski (M. P.) 1953, nr A-104, poz. 1399).

3 Zob. A. Chamera-Nowak, Rola Rady Czytelnictwa $i$ Ksiażki w upowszechnianiu czytelnictwa w l. 50. XX wieku w Polsce, [w:] Ksiażka i biblioteka w procesie komunikacji społecznej, pod red. R. Aleksandrowicz, H. Rusińskiej- Giertych, Wrocław 2015, s. 155-172.

4 Zob. A. Chamera-Nowak, Ksiązki, biblioteki i bibliotekarze na wsi polskiej w okresie stalinizmu w świetle dokumentów Centralnego Urzędu Wydawnictw, Przemystu Graficznego i Księgarstwa, „Rocznik Bibliologiczno-Prasoznawczy” 2013, t. 5 (16), s. 15-30; D. Jarosz, Codzienna mobilizacja. O propagandzie czytelnictwa książek w Polsce stalinowskiej i trudnościach jej badania, „Z Badań nad Książką i Księgozbiorami Historycznymi” 2011, t. 5, s. 298-299, 303; tenże, Dni Oświaty, Książki i Prasy w systemie propagandy kulturalnej władz Polski Ludowej 
Ten brak zrozumienia dla „rewolucji kulturalnej” wynikał prawdopodobnie z wielu czynników, w tym - z niskiego poziomu czytelnictwa samego aktywu partyjnego, niemającego nawyku czytania. Wskazują na to zachowane dokumenty - dotyczące funkcjonowania nie tylko bibliotek powszechnych, lecz także partyjnych, których sieć była tworzona od maja 1946 r. przez Polską Partię Robotniczą (PPR). Podstawę źródłową do omówienia funkcjonowania bibliotek partyjnych województwa warszawskiego stanowiły zachowane w Archiwum Akt Nowych dokumenty Komitetu Centralnego PPR (295/VII/84, 295/X/35) oraz akta Warszawskiego Komitetu Wojewódzkiego PZPR (1734) z Archiwum Państwowego Dokumentacji Osobowej i Płacowej. Analizowane dokumenty, które bezpośrednio dotyczą omawianych bibliotek, pochodzą z lat 1946-1954.

Warszawa po II wojnie światowej według podziału administracyjnego z 28 czerwca 1946 r. była miastem wydzielonym i istniała obok województwa warszawskiego ${ }^{5}$. W latach 1950-1957 nastąpiły kolejne liczne zmiany administracyjne na poziomie wojewódzkim, powiatowym i gminnym, w wyniku których Warszawa (nadal jako miasto wydzielone) weszła w skład województwa warszawskiego. W 1952 r. zlikwidowano powiat warszawski (powstały ponownie w 1944 r.).

Sprawy bibliotek i książek znajdowały się w orbicie zainteresowań władz komunistycznych od powstania Polskiego Komitetu Wyzwolenia Narodowego (PKWN) w 1944 r., a następnie tzw. Rządu Tymczasowego Rzeczypospolitej Polskiej, którego ministerstwo oświaty zajmowało się zabezpieczaniem ocalałych zbiorów bibliotecznych oraz - na polecenie premiera Edwarda Osóbki-Morawskiego - opracowaniem dekretu o bibliotekach gminnych ${ }^{6}$. Było to zgodne z sowieckimi wzorcami utrwalania zdobywanej władzy m.in. poprzez „uporządkowanie” polityki wydawniczej”, tj. uzależnienie jej od centralnego

1946-1956, [w:] Polska 1944/45-1989. Studia i materiaty, t. 10, red. J. Eisler, T. Szarota, K. Kosiński, Warszawa 2011, s. 43-60.

5 Rozporządzenie Rady Ministrów z dnia 29 maja 1946 r. w sprawie tymczasowego podziału administracyjnego Ziem Odzyskanych, Dz. U. 1946, Nr 28, poz. 177; Ustawa z dnia 28 czerwca 1950 r. o zmianach podziału administracyjnego Państwa, Dz. U. 1950, Nr 28, poz. 255.

6 Zob. J. Puchalski, Prace Józefa Grycza nad organizacją bibliotekarstwa publicznego w latach 1945-1949, cz. 1, „Z Badań nad Książką i Księgozbiorami Historycznymi” 2011, t. 5, s. 53-87.

7 Podstawowym stosowanym przez propagandę komunistyczną środkiem indoktrynacji było „słowo drukowane”, a sowiecka nauka o książce w rozumieniu systemu książki według ks. Antoniego W. Kwiatkowskiego, twórcy Instytutu Naukowego Badania Komunizmu, stanowiła „olbrzymi aparat techniczny", którego powstanie umożliwiło upaństwowienie środków produkcji wydawniczej, a tym samym - objęcie jej kontrolą partyjną, administracyjną i policyjną. Wśród elementów nadzoru i kontroli znajdował się tzw. „czynnik społeczny”, czyli m.in. członkowie partii. Zob. J. Puchalski, Ksiądz Antoni Wincenty Kwiatkowski i jego Instytut Naukowego Badania Komunizmu w Warszawie (INBK) w latach 1930-1937, [w:] Losy Polaków w okresie drugiej wojny światowej, red. A. Sielicki, Krasnodar 2015, s. 73-83; D. Jarosz, Władza a ksiązka społeczno-polityczna w PRL 1956-1989, „Z Badań nad Książką i Księgozbiorami Historycznymi” 2013-2014, t. 7-8, s. 133-172; S.A. Kondek, Władza i wydawcy. Polityczne uwarunkowania produkcji ksiażek w Polsce w latach 1944-1949, Warszawa 1993, passim. 
planisty. Zgodnie z tymi założeniami bibliotekarze mieli natomiast sterować ideowym czytelnictwem książek o treściach zgodnych z partyjnymi wytycznymi ${ }^{8}$. Efekt prac kierowanego przez Józefa Janiczka Wydziału Bibliotek Ministerstwa Oświaty ${ }^{9}$ stanowiło powołanie w listopadzie 1945 r. Rady Książki ${ }^{10}$ jako czynnika doradczego w sprawach produkcji i rozpowszechniania wydawnictw, a w marcu 1946 r. - Państwowego Instytutu Książki (PIK) w Lodzi pod kierownictwem Adama Łysakowskiego - do zadań tej jednostki należało głównie prowadzenie i koordynowanie badań bibliologicznych ${ }^{11}$. Ogłoszony 17 kwietnia $1946 \mathrm{r}$. Dekret o bibliotekach i opiece nad zbiorami bibliotecznymi był realizacją przedwojennych i wojennych prac nad ustawodawstwem bibliotecznym przede wszystkim Józefa Grycza ${ }^{12}$. Dekret, jak wspomniano, powoływał ogólnopolską sieć samorządowych bibliotek powszechnych, której utrzymanie powierzył państwu, a opiekę (poprzez Ministerstwo Oświaty) - Naczelnej Dyrekcji Bibliotek (NDB), czyli przemianowanemu Wydziałowi Bibliotek ${ }^{13}$. Kierownictwo NDB objął Grycz. Realizację dekretu miała wspomagać doradczo społeczna Państwowa Rada Biblioteczna, której jednak nigdy nie powołano ${ }^{14}$. W terenie miały to być wojewódzkie, powiatowe i gminne komitety biblioteczne podległe radom narodowym. Ich tworzenie przebiegało bardzo opornie, o czym świadczą kolejne uchwały Rady Państwa z lat 1947-1949 wzywające rady narodowe do jak najszybszej organizacji tychże komitetów wraz z instrukcjami oraz zaleceniami, aby w każdym był przedstawiciel PPR, a następnie - PZPR ${ }^{15}$.

8 Zob. T. Zarzębski, Geneza, życie i nauki dekretu, „Przegląd Biblioteczny” 1986, z. 3-4, s. 282; S.A. Kondek, Papierowa rewolucja. Oficjalny obieg ksiązek w Polsce w latach 1948-1955, Warszawa 1999, s. 81.

9 Zob. P. Lechowski, Karta z dziejów powojennego bibliotekarstwa polskiego. Wydziat Bibliotek w Ministerstwie Oświaty (luty 1945 marzec 1946), [w:] Między przeszłościa a przyszłościq. Książka, biblioteka, informacja naukowa - funkcje społeczne na przestrzeni wieków, pod red. M. Próchnickiej, A. Korycińskiej-Huras, Kraków 2007, s. 109-118.

10 Zob. J. Grycz, Problemy biblioteczne obecnej doby, „Przegląd Biblioteczny” 1946, s. 15; J. Muszkowski, Rada Ksiązki, „Przegląd Biblioteczny” 1947, z. 3-4, s. 147-155.

11 Zob. M. Korczyńska-Derkacz, Państwowy Instytut Ksią̇ki (1946-1949) i jego rola w rozwoju bibliologii, bibliotekarstwa i kultury ksiazkki w Polsce, Wrocław 2011.

12 Zob. J. Puchalski, Prace Józefa Grycza nad organizacja bibliotekarstwa publicznego w latach 1945-1949, cz. 2, „Z Badań nad Książką i Księgozbiorami Historycznymi” 2012, t. 6, s. 79-111; Półwiecze Dekretu o bibliotekach i opiece nad zbiorami bibliotecznymi. Refleksje i opinie bibliotekarzy, red. L. Biliński, Warszawa 1996.

13 J. Puchalski, Prace Józefa Grycza..., cz. 1, s. 69.

14 Państwowa Rada Biblioteczna powołana została dopiero na podstawie ustawy o bibliotekach z 1968 r. - zob. T. Orlińska, Informacja o działalności Państwowej Rady Bibliotecznej, „Przegląd Biblioteczny” 1969, z. 40, s. 365; B. Howorka, Krajowa Rada Biblioteczna wczoraj, dzisiaj i propozycje „,na jutro”, „Bibliotekarz” 2008, nr 3, s. 6-10.

15 Zob. Organizacja i działalność komitetów bibliotecznych, „Bibliotekarz” 1947, nr 9-10, s. 152-154; Archiwum Państwowe Dokumentacji Osobowej i Płacowej (APDOiP), Warszawski Komitet Wojewódzki (WKW) PZPR 1948-1999, 1734/I, Pismo W. Michalskiej, kierownika Biblioteki KC PZPR do Wydziału Propagandy w Węgrowie z dnia 6 sierpnia 1949 r., k. 1. 
Do końca 1947 r. powstał podstawowy szczebel sieci, czyli ponad 260 bibliotek powiatowych ${ }^{16}$. Rozbudowano także sieci bibliotek szkolnych, pedagogicznych, naukowych i związkowych. Organizacja bibliotek gminnych natrafiała na wiele przeszkód, przede wszystkim finansowych; wiele samorządów, głównie gminnych, nie uwzględniało w swoich budżetach wydatków na te placówki ${ }^{17}$ i tylko jedno województwo - kieleckie - na początku 1948 r. posiadało pełną sieć bibliotek powiatowych i gminnych z punktami bibliotecznymi w połowie gromad ${ }^{18}$. Do innych czynników ograniczających rozwój sieci bibliotek powszechnych należy zaliczyć także trudności lokalowe, materialne i kadrowe ${ }^{19}$. Władze nie były zadowolone z przebiegu „akcji bibliotecznej” - uważały, że jest zbyt mało placówek gminnych, a ich księgozbiory mają niezadawalającą zarówno wielkość, jak i zawartość. Rada Państwa przyjęła 5 marca 1948 r. uchwałę w sprawie upowszechniania książki i czytelnictwa w Polsce, powołującą Komitet Upowszechniania Książki $(\mathrm{KUK})^{20}$. Był to organ, którego struktura i zakres działania miały pomóc w budowie scentralizowanego partyjno-państwowego systemu obiegu książki oraz czytelnictwa ${ }^{21}$, dublujący funkcje NDB. Doprowadziło to w efekcie do przejęcia przez KUK kierownictwa nad organizacją sieci bibliotek, szczególnie gminnych. Odpowiedzialnymi za realizację władza uczyniła gminne i powiatowe rady narodowe, które zostały zobowiązane do wyposażenia i utrzymania lokalu bibliotecznego oraz zatrudnienia bi-

16 Biblioteki powiatowe miały być organizatorami sieci bibliotek gminnych, a do czasu ich powstania - pełnić rolę central bibliotecznych zaopatrujących wiejskie punkty biblioteczne w wymienne komplety książek - zob. P. Lechowski, Problemy i organizacja powszechnego bibliotekarstwa publicznego w Polsce w latach 1945-1951, „Roczniki Biblioteczne” 2011, R. 55, s. 105-107.

17 Zob. tamże, s. 101-102.

18 Zob. G. Gulińska, Biblioteki publiczne w Polsce w latach 1945-1955 - od autonomii do centralnie sterowanego obiegu książek (na przykladzie województwa kieleckiego), [w:] Książka, biblioteka, informacja - między podziatami a wspólnota, pod red. J. Dzieniakowskiej, Kielce 2007, s. 377-390.

19 Zob. A. Chamera-Nowak, Książki, biblioteki i bibliotekarze..., s. 15-30; Także za P. Lechowski: AAN, Ministerstwo Oświaty, Naczelna Dyrekcja Bibliotek, 6814, Stan i rozwój bibliotek. Sprawozdania [1949], k. 6-8.

20 Uchwała Rady Państwa w sprawie upowszechniania ksiażki i czytelnictwa w Polsce, „Bibliotekarz” 1948, nr 3, s. 33-34. (Uchwała ta nie została opublikowana, ale jej tekst rozesłano do różnych instytucji i redakcji gazet i czasopism).

21 KUK miał koordynować akcję upowszechniania czytelnictwa oraz wydawania tanich, masowych edycji najbardziej potrzebnych dzieł literatury polskiej, a także opracować plan wydawniczy na lata 1948-1949 - zob. M. Korczyńska-Derkacz, Badania czytelnictwa w Polsce w latach 1945-1950. Między potrzebami czytelniczymi a oczekiwaniami władzy, [w:] Czytanie, czytelnictwo, czytelnik, red. A. Żbikowska-Migoń, przy współudziale A. Łuszpak, Wrocław 2011, s. 332-334; S.A. Kondek, Czytelnik bez wtaściwości. Miejsce czytelnictwa w państwowym systemie obiegu ksiązek w latach 1949-1955, „Rocznik Biblioteki Narodowej” 1996, R. 32, s. 67-72; tenże, Wtadza i wydawcy. Polityczne uwarunkowania produkcji ksiażek w Polsce w latach 1944-1949, Warszawa 1993, s. 178-185. 
bliotekarza ${ }^{22}$. J. Grycza zwolniono w trybie natychmiastowym z NDB w lutym 1949 r., wkrótce po tym, jak w styczniu tegoż roku otwierał uroczyście sieć bibliotek publicznych we wsi Pustelnik (oficjalnie otwarto wówczas jednocześnie w całym kraju 1600 bibliotek gminnych i 18000 punktów bibliotecznych), co miało symbolicznie zwieńczyć realizację dekretu z 1946 r. Po odejściu Grycza nadzór nad NDB objął Wydział Oświaty i Kultury KC PZPR, co było wraz z powołaniem KUK początkiem centralizacji zarządzania oraz upolitycznienia bibliotekarstwa ${ }^{23}$. Zadania KUK ${ }^{24}$ przejęła w 1949 r. zorganizowana na wzór radziecki Centralna Komisja Wydawni$\mathrm{cza}^{25}$. Również w 1949 r. podjęto decyzję o likwidacji PIK, co nastąpiło oficjalnie w marcu 1950 r. Sama NDB przestała istnieć z końcem października 1951 r. - została zastąpiona przez Centralny Zarząd Bibliotek usytuowany w Ministerstwie Kultury i Sztuki. Nadzór nad różnymi typami bibliotek został rozproszony między poszczególne resorty, co znacznie utrudniło efektywne zarządzanie poszczególnymi sieciami bibliotecznymi.

\section{Biblioteka KC PPR w Alei Róż}

Sieć bibliotek, które miały być wsparciem w szkoleniu ideologicznym aktywu PPR, zaczęto tworzyć w 1946 r. na bazie komitetów wojewódzkich i powiatowych partii. Jako pierwsza, już w lutym 1945 r., powstała biblioteka Komitetu Centralnego PPR ${ }^{26}$. Jej podstawę stanowiło około tysiąc książek przywiezionych z Lublina do Warszawy, które zostały wraz 1500 innymi zinwentaryzowane i skatalogowane, a następnie udostępnione 27 marca aktywowi partyjnemu. We wrześniu 1946 r. biblioteka liczyła już 30000 woluminów (w tym 16000 zinwentaryzowanych) oraz ponad 900 tytułów prasowych w ośmiu językach. Zajmowała pięć pokoi w gmachu przy Alei Róż 2, w których znajdowała się biblioteka podręczna, wypożyczalnia, gabinet partyjny, gabinet historyczny, dział prohibitów, czytelnia pism, poradnia konsultacyjna biblioteczna i techniczna, działy organizacji sieci bibliotecz-

22 Zob. J. Puchalski, Prace Józefa Grycza..., cz. 2, s. 96.

23 Zob. A. Mężyński, Bibliotekarstwo polskie w latach 1948-1956. Kłopoty historyków, „Poradnik Bibliotekarza” 1990, nr 1-3, s. 21-22.

24 KUK, który oficjalnie był ciałem o charakterze społecznym, formalnie został zlikwidowany dopiero w 1952 r., a jego agendy w zakresie czytelnictwa i upowszechniania książki przejęła Rada Czytelnictwa i Książki - AAN, Centralny Urząd Wydawnictw Przemysłu Graficznego i Księgarstwa (CUWPGiK), 42, j. 38, Uchwała Prezydium Rządu nr 747/52 z dnia 10 września 1952 r. w sprawie zniesienia Komitetu Upowszechniania Książki.

25 Uchwała Komitetu Ministrów do Spraw Kultury z dnia 29 lipca 1949 r. w sprawie koordynacji prac nad planem wydawniczym, M. P. 1949, nr A-54, poz. 729.

26 Archiwum Akt Nowych (AAN), Polska Partia Robotnicza Komitet Centralny (PPR KC), 295/VII/84, Sprawozdanie z biblioteki KC PPR na dzień 1 IX 46 r., k. 10-11. 
nej, ekspedycji prasy, introligatornia i sekretariat. Biblioteka posiadała katalogi: alfabetyczny, działowy i przedmiotowy ${ }^{27}$. Dział bibliograficzny sporządzał m.in. szereg spisów bibliograficznych dotyczących tematów aktualnych i historycznych (np. „Polska w obliczu Niemiec”, „Węzłowe zagadnienie gospodarcze za rok 1947”, „Historia ruchu robotniczego”, „Powstanie Listopadowe") oraz wydawał biuletyn biblioteczny. Placówka zajmowała się także przygotowywaniem i wydawaniem instrukcji bibliotecznych, w których zalecano uporządkowanie zbiorów według specjalnie przygotowanych tablic klasyfikacji dziesiętnej (marksizm i leninizm znalazł się w naukach społecznych i prawnych, oznaczony symbolem $3 \mathrm{~K})^{28}$.

Jesienią 1946 r. biblioteka KC PPR miała około tysiąca czytelników, którzy wypożyczali średnio jedną książkę miesięcznie. Nowych czytelników przybywało ok. 40 miesięcznie. Z czytelni korzystało średnio miesięcznie ok. 200 osób. Wanda Michalska, kierowniczka biblioteki KC PPR, uważała przy tym, że stan czytelnictwa jest „bardzo nikły”29.

W maju 1946 r. przystąpiono do organizacji partyjnej sieci bibliotek. Pierwszy etap stanowiło wysłanie okólników i formularzy do komitetów wojewódzkich i powiatowych PPR. Rezultaty tego działania, jak zauważała W. Michalska, były niewielkie - odpowiedzi przysłało dziesięć komitetów wojewódzkich i tylko 33 powiatowe, do tego odpowiedni budżet zatwierdzono dopiero po interwencjach W. Michalskiej w grudniu tegoż roku ${ }^{30}$. We wrześniu 1946 r. 61 komitetów powiatowych posiadało 7661 książek, a dziesięć komitetów wojewódzkich - 6352 książek $^{31}$. W. Michalska w swoim sprawozdaniu ubolewała, że „nie ma jeszcze należytego zrozumienia dla tych spraw ani w wojewódzkich wydziałach propagandy, ani nawet w Wydziale Propagandy KC"32. Skutkowało to brakiem pieniędzy na organizację sieci oraz niedopuszczeniem kierowniczki biblioteki KC PPR do głosu podczas narady wojewódzkich kierowników propagandy. Jednak jak wynika ze wspomnianego sprawozdania, miesięcznie organizowano dziesięć bibliotek, przede wszystkim na Ziemiach Zachodnich.

Biblioteki wojewódzkie i powiatowe były zasilane m.in. poprzez przesyłki książek i broszur z biblioteki KC PPR, która pomagała także w zorganizowaniu bibliotek podręcznych w domach wczasowych, przy koloniach

27 Zob. S. Żurawicki, Biblioteka KC PPR, „Bibliotekarz” 1946, nr 5, s. 120.

28 Instrukcja jak zorganizować biblioteki partyjne, [Warszawa], Biblioteka KC PPR, [b.r.w.], s. VIII.

29 AAN, PPR KC, 295/VII/84, Sprawozdanie z biblioteki KC PPR na dzień 1 IX 46 r., k. 11.

30 AAN, PPR KC, 295/VII/84, Sprawozdanie z biblioteki za miesiąc listopad [1946 r.], k. 24-25.

31 AAN, PPR KC, 295/VII/84, Sprawozdanie z biblioteki KC PPR na dzień 1 IX 46 r., k. 11.

32 Jak wyżej. 
dziecięcych, kursach partyjnych i samorządowych czy szkołach i kołach partyjnych $^{33}$. Biblioteki nakłaniano do składania zobowiązań do zakupu miesięcznie książek na określone kwoty - 5000 zł lub 10000 zł (gdy biblioteki miejska i powiatowa zostały połączone) $)^{34}$. Oprócz tego biblioteka KC PPR wysyłała egzemplarze bezpłatne ${ }^{35}$. Wśród nich znajdowały się tzw. „biblioteczki zorganizowane", liczące od kilkunastu do kilkudziesięciu woluminów, zaopatrzone w metryczki książek, katalog działowy i spis alfabetyczny. Dystrybucją książek zajmował się dział księgarsko-rozdzielczy referatu sieci bibliotecznej.

Biblioteka KC PPR przeprowadzała inspekcje bibliotek partyjnych przy komitetach wojewódzkich, miejskich, dzielnicowych (na terenie Warszawy) i powiatowych, w szkołach wojskowych oraz terenowych oddziałach Spółdzielni Wydawniczej „Książka”, gdzie sprawdzano realizację akcji „KUK”, Niestety sprawozdania $\mathrm{z}$ kontroli przeprowadzonych w czerwcu, sierpniu i wrześniu 1948 r. nie odzwierciedlają stanu faktycznego, bowiem nie wykazują inspekcji zakończonych negatywną oceną. Można się o nich pośrednio dowiedzieć z notek z powtórnych wizytacji. W większości skontrolowanych bibliotek były wyznaczone osoby do prowadzenia biblioteki, m.in. maszynistki, instruktorzy kolportażu, kolporterzy, instruktorzy propagandowi, drugi sekretarz, kierownik wydziału personalnego, czy sekretarki. Tylko w trzech na kilkadziesiąt zatrudniono bibliotekarki. W pozostałych komitetach osoby do prowadzenia bibliotek miały dopiero zostać wytypowane.

Po powstaniu Polskiej Zjednoczonej Partii Robotniczej biblioteka KC PPR ${ }^{37}$ oraz biblioteki terenowe weszły w struktury PZPR. W 1949 r. zostały przypisane do Ośrodków Propagandy Partyjnej poszczególnych szczebli ${ }^{38}$.

33 AAN, PPR KC, 295/X/35, Inspekcja Bibliotek Partyjnych w lipcu 1948 r. [inspekcja została przeprowadzona w dniach 12-26 czerwca 1948 r.], k. 66-67; tamże, Inspekcja Bibliotek Partyjnych w sierpniu 1948 r., k. 77-79; tamże, Inspekcja Bibliotek Partyjnych we wrześniu 1948 r., k. 89-90.

${ }^{34}$ APDOiP, WKW PZPR 1948-1999, 449, Z odprawy bibliotekarzy pow. w woj. warszawskim, k. 2-6.

35 Np. AAN, PPR KC, 295/X/35, Sprawozdanie z biblioteki za miesiąc wrzesień 1948 r., k. 87.

36 KUK przejął zadania organizacji sieci bibliotek samorządowych - wiejskich i małomiasteczkowych. W tym przypadku mowa jest o akcji zakładania 20 tys. punktów bibliotecznych AAN, PPR KC, 295/X/35, Sprawozdanie z biblioteki za miesiąc wrzesień 1948 r., k. 80.

37 Jej kierownikiem nadal była W. Michalska, która została w 1950 r. dyrektorem NDB, po Józefie Skrzypku (1949-1950) - zob. A. Mężyński, dz. cyt., s. 20-21.

38 W Warszawie biblioteka Stołecznego Ośrodka Propagandy Partyjnej Komitetu Warszawskiego PZPR mieściła się przy ul. Mokotowskiej 25 i pełniła na początku lat sześćdziesiątych funkcje instrukcyjno-metodyczne w stosunku do 12 bibliotek ośrodków dzielnicowych i 22 bibliotek powiatowych PZPR woj. warszawskiego - zob. A. Łuczyńska, H. Wiącek, Informator o bibliotekach w Polskiej Rzeczypospolitej Ludowej, Warszawa 1961, s. 108, poz. 611. 
Biblioteka KC PZPR prowadziła szkolenia oraz konsultacje dla bibliotekarzy partyjnych. W jej strukturze działał gabinet metodyczny, którego zadaniem było przede wszystkim opracowywanie wskazówek do pracy z czytelnikiem. Bibliotekarze partyjni mieli także obowiązkowo wchodzić w skład komitetów bibliotecznych oraz być członkami Związku Bibliotekarzy i Archiwistów Polskich ${ }^{39}$.

\section{Sieć bibliotek partyjnych w województwie warszawskim}

Sieć bibliotek partyjnych tworzona była, jak wspomniano, od 1946 r., jednak według zachowanych sprawozdań jeszcze w 1949 r. nie działała ona prawidłowo. Na Mazowszu biblioteki istniały wówczas przy wszystkich komitetach powiatowych oraz gminnym w Wawrze i miejskim we Włochach ${ }^{40}$. $\mathrm{Z}$ zachowanych dokumentów z odprawy bibliotekarzy powiatowych z dnia 31 maja 1949 r. wynika, że funkcjonowało 26 bibliotek powiatowych, z czego brak danych na temat czterech, osiem było nieczynnych, poza tym większość posiadała nieopracowany księgozbiór, nie prowadziła ksiąg inwentarzowych, nie miała katalogu oraz druków bibliotecznych ${ }^{41}$. Opracowanym księgozbiorem mogły wykazać się placówki w Płocku, Siedlcach, Ciechanowie, Działdowie i Węgrowie (tutaj bibliotekarz otrzymał polecenie zastosowania się do instrukcji biblioteki $\mathrm{KC}$ ). W pozostałych przypadkach w ogóle nie ma informacji $\mathrm{w}$ sprawozdaniu na ten temat. Wiadomo natomiast, że w czterech bibliotekach prowadzone były księgi inwentarzowe (Mława, Płock, Ciechanów, Działdowo), w dwóch - katalogi (Mława i Płock). Z powodu niekonsekwentnych zapisów niewiele można powiedzieć także o samych bibliotekarzach oraz lokalu bibliotecznym. W przypadku biblioteki w Żyrardowie podano informację, że placówkę prowadził pracownik komitetu miejskiego PZPR, w Gostyninie - uczennica pracująca trzy godziny dziennie za 5 tys. zł; w Pułtusku bibliotekarz był na „bardzo niskim poziomie”, a w Płońsku miał ukończone siedem klas szkoły powszechnej. W Pruszkowie bibliotekarka nie chciała wypożyczać nieopracowanych książek i została w związku z tym upomniana - powinna prowadzić specjalny zeszyt ewidencyjny. Z kontroli tej biblioteki w następnych miesiącach wynika, że jej księgozbiór znajdował się w szafie w świetlicy, a placówka była czynna w godz. 15-19. Bibliotekarka, która pracowała w Urzędzie Wojewódzkim w Pruszkowie, przeważnie nie była jednak

39 APDOiP, WKW PZPR 1948-1999, 449, Sprawozdanie z odprawy bibliotekarzy powiatowych z dnia 31 maja 1949 r., k. 3.

40 Wawer i Włochy przyłączono do Warszawy w $1951 \mathrm{r}$.

41 APDOiP, WKW PZPR 1948-1999, 449, Sprawozdanie z odprawy bibliotekarzy powiatowych z dnia 31 maja 1949 r., k. 2-6. 
w stanie w tym czasie wypożyczać książek, bowiem odbywały się wówczas różnego rodzaju zebrania ${ }^{42}$. Jedynie w Przasnyszu biblioteka posiadała swój lokal. W Mławie w siedzibie biblioteki urządzono czytelnię prasy; w Siedlcach placówka mieściła się w pokoju przejściowym, gdzie było brudno, a sekretarz zamykał go bez uzgodnienia z bibliotekarką; w Garwolinie i we Włochach ${ }^{43}$ książki znajdowały się w szafie współdzielonej w wydziałem propagandy. W przypadku pięciu bibliotek podano dane dotyczące liczby czytelników: Mława - 45, Płock - 204, Siedlce - 93, Węgrów - 30 i Garwolin - 35. Byli to głównie pracownicy umysłowi oraz członkowie ZMP, wykładowcy i uczestnicy kursów i szkoleń partyjnych. Tylko w przypadku biblioteki w Ciechanowie zaznaczono, że korzystało z niej oprócz członków ZMP także pięciu robotników i dwóch chłopów.

Tabela 1. Wielkość księgozbiorów poszczególnych bibliotek powiatowych PZPR w województwie warszawskim w maju 1949 r.

\begin{tabular}{|l|l|}
\hline Miejscowość & Ilość wol. \\
\hline Ciechanów & 612 \\
\hline Działdowo & 251 \\
\hline Garwolin & 104 \\
\hline Gostynin & 44 \\
\hline Grójec & 93 \\
\hline Grodzisk Mazowiecki & b.d. \\
\hline Maków & b.d. \\
\hline Mińsk Mazowiecki & b.d. \\
\hline Mława & 409 \\
\hline Ostrołęa & b.d. \\
\hline Ostrów Mazowiecka & 352 \\
\hline Płock & 730 \\
\hline Płońsk & 200 \\
\hline Pruszków & 694 \\
\hline Przasnysz & 178 \\
\hline Pułtusk & 142 \\
\hline Siedlce & 512 \\
\hline Sierpc & 92 \\
\hline Sochaczew & 141 \\
\hline Sokołów & 109 \\
\hline Wawer & 50 \\
\hline Węgrów & 400 \\
\hline Włochy & 120 \\
\hline Wołomin & 28 \\
\hline Żyrardów & 351 \\
\hline
\end{tabular}

Oprac. własne na podstawie: Sprawozdanie z odprawy bibliotekarzy powiatowych z dnia 31 maja 1949 r., APDOiP, WKW PZPR 1948-1999, 449, k. 2-6.

42 APDOiP, WKW PZPR 1948-1999, 449, Sprawozdanie z działalności biblioteki przy Wojewódzkim Komitecie PZPR za m-ce czerwiec i lipiec 1949 r., k. 7.

43 Tamże, k. 8. 
Wielkość poszczególnych księgozbiorów była zróżnicowana: od 730 książek w Płocku i 694 w Pruszkowie po 44 woluminy w Gostyninie i 28 w Wołominie. W Płocku i Siedlcach (512 woluminów) liczebność księgozbioru wynikała z połączenia biblioteki miejskiej i powiatowej. Wypożyczano książki, które nie były ani oprawione ani opracowane; rejestrowano je w specjalnych zeszytach. Bibliotekarce w Pruszkowie, która nie chciała udostępniać nieopracowanych książek, zwrócono ,uwagę na niesłuszne stawianie sprawy" i nakazano, by biblioteka była czynna trzy razy w tygodniu. Natomiast bibliotekarz w Płońsku otrzymał upomnienie za wypożyczanie „bez żadnej kontroli”. Ze sprawozdania wynika również, że planowano łączenie bibliotek przy komitetach miejskich i powiatowych PZPR, tak jak to zrobiono w przypadku Płocka.

We wzmiankowanym sprawozdaniu znajdują się również uwagi dotyczące stosunku aktywu partyjnego do bibliotek. W Węgrowie bibliotekarz uzgadniał z sekretarzem komitetu powiatowego PZPR dobór książek dla uczestników szkoleń. Zupełnie odmienna sytuacja panowała w Siedlcach, gdzie bibliotekarka żaliła się na złe warunki pracy, przejściowy pokój, brud i sekretarza, który zamykał bibliotekę, a klucz zabierał ze sobą, oraz na nieprzychylny stosunek komitetu do spraw bibliotecznych - ,aktyw Komitetu absolutnie nie interesuje się biblioteką i książek nie wypożycza" ${ }^{\prime 4}$.

Biblioteka KW PZPR, której podlegały bezpośrednio biblioteki przy miejskich i powiatowych komitetach PZPR, oprócz systematycznej kontroli i pomocy przy organizacji placówek, zajmowała się także przygotowywaniem „biblioteczek zorganizowanych”, np. w lipcu 1949 r. opracowano 301 książek dla gromady Górki w gminie Kampinos (powiat Sochaczew), tj. zinwentaryzowano je i założono katalog alfabetyczny. Dla księgozbioru zakupiono także specjalną szafę ${ }^{45}$. Przy opracowywaniu księgozbiorów pomagali także bibliotekarze bibliotek publicznych - np. w Wawrze w tego typu pomoc włączył się kierownik powiatowej biblioteki publicznej w Aninie ${ }^{46}$.

Kontrole bibliotek i odprawy bibliotekarzy partyjnych w województwie warszawskim w 1949 r. wykazały, że tworzona od 1946 r. sieć ciągle jest w fazie organizacyjnej. Większość placówek nie miała swojego lokalu, a książki przechowywano w szafach, głównie w świetlicach. Księgozbiory, mimo dokładnych instrukcji biblioteki KC PZPR, były nieopracowane, a osoby wyznaczone do prowadzenia bibliotek nie posiadały fachowego

44 APDOiP, WKW PZPR 1948-1999, 449, Sprawozdanie z odprawy bibliotekarzy powiatowych z dnia 31 maja 1949 r., k. 4.

45 APDOiP, WKW PZPR 1948-1999, 449, Sprawozdanie z działalności biblioteki przy Wojewódzkim Komitecie PZPR za m-ce czerwiec i lipiec 1949 r., k. 8.

46 APDOiP, WKW PZPR 1948-1999, 449, Sprawozdanie z działalności biblioteki Komitetu Powiatowego PZPR w Wawrze, k. 29. 
przygotowania. Problemy ze sprawnym działaniem bibliotek w niektórych przypadkach wynikały też $\mathrm{z}$ niechęci do nich komitetów partyjnych, np. w Siedlcach, gdzie ,aktyw Komitetu absolutnie nie interesuje się biblioteką i książek nie wypożycza" ${ }^{47}$. Część komitetów, np. w Sierpcu i Płońsku, nie chciała zadeklarować obowiązkowych miesięcznych kwot na zakup książek. Rola i zadania bibliotek partyjnych, które miały być zapleczem dla ideologicznego kształcenia i samokształcenia aktywu bibliotecznego, okazywała się trudna do zrealizowania.

Wyniki prowadzonych w latach pięćdziesiątych XX w. akcji współzawodnictwa bibliotek także wypadają na niekorzyść bibliotek partyjnych. W 1952 r. komitety powiatowe PZPR tylko w kilku wypadkach interesowały się ,żywo" współzawodnictwem - w Przasnyszu, Siedlcach, Mławie, Sierpcu i Ciechanowie, ale w tych powiatach sprawa bibliotek i czytelnictwa omawiana była na posiedzeniach komitetów partyjnych, co miało zasadniczy wpływ na włączenie się placówek we wskazaną akcję ${ }^{48}$. W przypadku pozostałych nie pomogło nawet specjalne zarządzenie wydane przez Prezydium Wojewódzkiej Rady Narodowej ${ }^{49}$.

Mimo podejmowanych starań czytelnictwo aktywu partyjnego na poziomie powiatów i gmin było niskie. W powiecie ciechanowskim tłumaczył się on brakiem czasu. W Powiatowym Związku Gminnych Spółdzielni (PZGS) w Ciechanowie na 30 członków partii w 1954 r. tylko trzech prenumerowało codzienną prasę partyjną, reszta została „przymusowymi” prenumeratorami po interwencji KP PZPR ${ }^{50}$. W powiecie grójeckim na 3395 członków partii i kandydatów prasę prenumerowało w 1954 r. ok. 1100, w tym 700 - ,Trybunę Ludu” a 350 - „Trybunę Mazowiecką”. Czasopisma rolne i fachowe zamawiało 250 osób, co stanowiło $10 \%$ ogółu prenumeratorów tych czasopism w powiecie ${ }^{51}$. Oprócz tego na 624 agitatorów partyjnych 34 prenumerowało „Notatnik Agitatora”, a na 21 prelegentów kursów partyjnych 12 prenumerowało „Notatnik Referenta”. KP PZPR w Grójcu donosił także, że prasa docierała do gmin niesystematycznie $\mathrm{z}$ dwu-, trzydniowym opóźnieniem, a w skrajnych wypadkach - nawet dwu-, trzytygodniowym (m.in. w Nowej Wsi) lub w niektóre dni w ogóle nie była dostarczana. Na przykład prenu-

${ }^{47}$ APDOiP, WKW PZPR 1948-1999, 449, Sprawozdanie z odprawy bibliotekarzy powiatowych z dnia 31 maja 1949 r., k. 4.

48 APDOiP, WKW PZPR 1948-1999, 449, Sprawozdanie z II etapu współzawodnictwa bibliotek województwa warszawskiego w okresie od dn. 1 XI 1951 - 31 III 1952 r., k. 31-32.

49 Tamże, k. 32.

50 APDOiP, WKW PZPR 1948-1999, 449, Sprawozdanie Komitetu Powiatowego PZPR w Ciechanowie o stanie czytelnictwa wśród członków partii na terenie pow. ciechanowskiego [z września 1954 r.], k. 60.

51 APDOiP, WKW PZPR 1948-1999, 449, Sprawozdanie Komitetu Powiatowego PZPR w Grójcu o stanie czytelnictwa wśród członków Partii na terenie pow. grójeckiego, k. 65-66. 
merator z gromady Rytomoczydła w lipcu 1954 r. otrzymał tylko osiem numerów „Trybuny Ludu”, a w gminie Borowe listonosz prasę zakopywał lub chował w stogach siana ${ }^{52}$. Ze sprawozdań $\mathrm{z}$ obu wymienionych powiatów wynika także, że poza pojedynczymi przypadkami słabe było również wśród aktywu partyjnego czytelnictwo książek.

We wrześniu 1954 r. Egzekutywa KW PZPR (w Warszawie), po wysłuchaniu sprawozdań z komitetów powiatowych w Grójcu i Ciechanowie o stanie czytelnictwa książek i prasy ${ }^{53}$ wśród członków partii, podjęła specjalną uchwałę w tej sprawie, bowiem ,poważna część członków partii nie czyta prasy partyjnej, nie korzysta z literatury marksistowskiej i politycznej oraz z literatury pięknej" ${ }^{54}$. Zalecono m.in. organizację dyskusji o przeczytanych książkach i urządzanie raz w tygodniu „prasówki” dla aktywu.

W 1949 r. biblioteki partyjne, jak wspomniano, zostały przypisane do Ośrodków Propagandy Partyjnej (OPP). W województwie warszawskim zorganizowano sześć większych bibliotek z pełnymi etatami bibliotecznymi: w Ciechanowie, Otwocku, Płocku, Pruszkowie, Siedlcach i Żyrardowie (połączone biblioteki miejskie i powiatowe) oraz 23 tzw. biblioteki podręczne w pozostałych powiatach, prowadzone przez kierowników POPP. Według sprawozdań z kontroli przeprowadzonej w 1963 r. wynika, że nadal nie wszystkie biblioteki posiadały księgi inwentarzowe, druki biblioteczne, katalogi, karty czytelników i karty książek oraz nie prowadziły ewidencji czytelników, rejestracji wypożyczeń i sprawozdań ${ }^{55}$. Niezmiennie wśród czytelników znajdowało się niewielu pracowników aparatu PZPR (17\%) oraz wykładowców szkoleń partyjnych (18\%). Na 28 bibliotekarek wykształcenie średnie miało 16, niepełne średnie - dziewięć, a podstawowe - trzy. Natomiast przygotowanie zawodowe posiadały dwie osoby, trzy uzupełniały je na zaocznym dwuletnim kursie bibliotekarskim. Poprawiła się za to znacznie sytuacja lokalowa, bo tylko w przypadku trzech bibliotek została

52 Tamże, k. 66.

53 Bardzo niską prenumeratę „Trybuny Ludu” wśród gminnego aktywu partyjnego wykazały m.in. kontrole przeprowadzone w $1951 \mathrm{r}$. w powiecie płockim. Stwierdzono, że np. gazety tej komitet $\mathrm{w}$ Bądkowie nie prenumeruje, ale robi to miejscowy ksiądz i usunięty ze stanowiska dawny sekretarz komitetu gminnego. Natomiast w 1954 r. w powiecie ciechanowskim na 4306 członków partii i kandydatów prenumeratą objętych było ok. 3000. Jeden egzemplarz „Trybuny Ludu” przypadał na czterech aktywistów, a „Trybuny Mazowieckiej” - na ośmiu - APDOiP, WKW PZPR 1948-1999, 449, Sprawozdanie z delegacji służbowej, odbytej w terminie od dnia 5 II do 12 II [1951 r.] na teren pow. Płock, woj. Warszawskie [sic!] w celu zbadania stanu czytelnictwa prasy na wsi, k. 37-50; tamże, Sprawozdanie Komitetu Powiatowego PZPR w Ciechanowie o stanie czytelnictwa wśród członków partii na terenie pow. ciechanowskiego z września 1954 r., k. 59.

54 APDOiP, WKW PZPR 1948-1999, 449, Uchwała w sprawie czytelnictwa książek i prasy wśród członków partii, k. 51-53.

55 APDOiP, WKW PZPR 1948-1999, 449, Informacja o czytelnictwie i stanie organizacyjnym bibliotek przy Powiatowych Ośrodkach Propagandy Partyjnej, k. 161-168. 
ona oceniona jako niezadowalająca - w Gostyninie biblioteka dzieliła pokój z wydziałem rolnym, w Grodzisku Mazowieckim - dysponowała salą konferencyjną, a w Ostrowi Mazowieckiej - pokojem przechodnim. Księgozbiory były nieuporządkowane, zawierały wiele tytułów zdezaktualizowanych lub takich, które nie odpowiadały profilowi pracy POPP; ponadto pojawiały się nadmierne ilości egzemplarzy tych samych tytułów ${ }^{56}$.

Wprawdzie poszczególne egzekutywy KP PZPR zajmowały się stanem czytelnictwa wśród członków partii, ale - jak zauważono w sprawozdaniu KP PZPR - „samo przygotowanie materiałów i opracowanie wniosków miało charakter formalny, dlatego też sytuacja na odcinku czytelnictwa nie uległa zasadniczej poprawie"s7. Takie pozorne działania związane z czytelnictwem i bibliotekami prowadzono przez wiele lat. Analiza dokumentów z początku lat sześćdziesiątych wskazuje, że niewiele się zmieniło i egzekutywy wojewódzkie czy powiatowe nadal wzywały zarówno aktyw, jak i szeregowych członków partii do interesowania się sprawami czytelnictwa, aby dawali oni ,przykład korzystania z książek i prasy oraz byli agitatorami czytelnictwa w swoim środowisku" ${ }^{\prime 5}$. Nie wzrastało także czytelnictwo ani książek, ani prasy, chyba że doraźnie i raczej „na papierze” - dla celów statystyki po interwencji wyższych władz partyjnych. Zachowane sprawozdania pokazują, że aktyw partyjny w powiatach i gminach z reguły nie był zainteresowany bibliotekami powszechnymi i problemem rozwoju czytelnictwa, a czasem wręcz okazywał niechęć wobec tych spraw, które traktował jak dodatkowy obowiązek. Zwykle kończyło się więc na polityczno-ideologicznym wsparciu ze strony rad narodowych, co miało wpływ także na przydzielane bibliotekom lokale, czy wyposażenie w sprzęt biblioteczny ${ }^{59}$. Do zwykłych praktyk należało także kierowanie bibliotekarzy przez rady narodowe do innych prac, np. przy akcjach żniwnych czy skupowych ${ }^{60}$.

Do tego aktyw partyjny przymuszany był do uczestnictwa w społecznych komitetach bibliotecznych, a później radach czytelnictwa i książki, do zadań których należał m.in. nadzór nad działalnością bibliotek, rozwojem czytelnictwa oraz aktywizacja w tym względzie rad narodowych ${ }^{61}$. Niechęć wobec spraw bibliotek i czytelnictwa, szczególnie na szczeblu gmin i gromad, wy-

\footnotetext{
56 APDOiP, WKW PZPR 1948-1999, 449, Informacja o akcji porządkowania bibliotek Powiatowych Ośrodków Propagandy Partyjnej, k. 169.

57 APDOiP, WKW PZPR 1948-1999, 449, Sprawozdanie Komitetu Powiatowego PZPR w Ciechanowie o stanie czytelnictwa wśród członków partii na terenie pow. ciechanowskiego [z września 1954 r.], k. 60.

58 APDOiP, WKW PZPR 1948-1999, 449, Wnioski Egzekutywy WKW PZPR z dnia 9 II 1962 r. w sprawie rozwoju czytelnictwa w woj. Warszawskim [sic!], k. 155.

59 AAN, CUWPGiK, 65, Biblioteki w województwie warszawskim [1952 r.], knlb.

60 AAN, CUWPGiK, 65, Sprawozdanie z wyjazdów odbytych w celu zebrania danych dotyczących stanu upowszechniania czytelnictwa i książki w powiecie pułtuskim [1952 r.], knlb.

61 A. Chamera-Nowak, Rola Rady Czytelnictwa ..., dz. cyt., s. 156, 162-163.
} 
nikająca z niskiego poziomu czytelnictwa działaczy partyjnych, znajdowała odzwierciedlenie w funkcjonowaniu zarówno sieci bibliotek partyjnych, jak i powszechnych. Egzekutywy KP PZPR najbardziej niepokoiło to, że aktyw powiatowy, gminny i gromadzki nie czuł potrzeby podnoszenia „poziomu ideologicznego", co przekładało się na słabą walkę „organizacji partyjnych o spółdzielczość produkcyjną, realizację obowiązków wsi wobec państwa i ideologiczno-ekonomiczną walkę z kułakiem" ${ }^{62}$. Podobnie jak w przypadku bibliotek powszechnych kończyło się na zaleceniach formalnych, kolejnych odezwach i rozporządzeniach, które w żaden sposób nie wpływały zasadniczo na podniesienie czytelnictwa szeregowych i funkcyjnych członków partii.

\section{Streszczenie}

Artykuł przedstawia sytuację bibliotek działających przy miejskich i powiatowych komitetach PZPR woj. warszawskiego (wg podziału administracyjnego obowiązującego w latach 1946-1954), a także wpływ działalności tych placówek na czytelnictwo członków partii. Podstawę źródłową stanowią różnego rodzaju zachowane w Archiwum Akt Nowych dokumenty Komitetu Centralnego PPR (295/VII/84, 295/X/35) oraz akta Warszawskiego Komitetu Wojewódzkiego PZPR (1734) z Archiwum Państwowego Dokumentacji Osobowej i Płacowej. Zachowane dokumenty, które bezpośrednio dotyczą omawianych bibliotek, pochodzą z lat 1946-1954 r. Sieć bibliotek PPR tworzona była od 1946 r. Jako pierwsza powstała już w lutym 1945 r. biblioteka Komitetu Centralnego PPR. Po utworzeniu Polskiej Zjednoczonej Partii Robotniczej biblioteka KC PPR oraz biblioteki terenowe weszły jej w struktury. W 1949 r. zostały przypisane do Ośrodków Propagandy Partyjnej poszczególnych szczebli. W woj. warszawskim w 1949 r. działało 25 takich bibliotek. Według zachowanych dokumentów placówki te nie wpłynęły zasadniczo na podniesienie poziomu czytelnictwa ani lokalnego aktywu partyjnego, ani szeregowych działaczy. Można wnioskować, że niechęć do spraw bibliotek i czytelnictwa, szczególnie na szczeblu gmin i gromad, wynikająca z niskiego poziomu czytelnictwa działaczy partyjnych, znajdowała odzwierciedlenie w funkcjonowaniu zarówno sieci bibliotek partyjnych, jak i powszechnych. Postawa lokalnych działaczy partyjnych przekładała się na podejmowanie przez władze wielu doraźnych i pozornych działań w zakresie rozwoju czytelnictwa.

Slowa kluczowe: biblioteki Polskiej Partii Robotniczej 1945-1949 - biblioteki PZPR 1949-1954 - czytelnictwo - stalinizm - województwo warszawskie.

${ }^{62}$ APDOiP, WKW PZPR 1948-1999, 449, Uchwała w sprawie czytelnictwa książek i prasy wśród członków partii, k. 51. 
Summary

\section{Libraries and librarians of the Polish United Workers' Party (PUWP) agendas in Mazovia region in the years 1949-1954 in the light of the documents of Central Committee of Polish Workers' Party and Warsaw Voivodship PUWP Committee}

The article presents situation of the libraries of municipal and local PUWP committees of Warsaw Voivodship (according to then administrative division of a country) as well as their influence on reading behaviour of party members. Presentation is based on different kind of documents of Central Committee of Polish Workers' Party (kept in Central Archives of Modern Records 295/VII/84, 295/X/35) and Warsaw Voivodship PUWP Committee (kept in State Archives Documentation Personal and Remuneration, 1734). Preserved documents, which are directly connected with discussed libraries are dated from the period 1946-1954. The network of Polish Workers Party's (PWP) libraries was created from the year 1946 onward. The library of the Central Committee of PWP was established as the first one as soon as in February 1945. After the Polish United Workers' Party (PUWP) was started PWP's Central Committee library and local PWP's libraries were merged into PUWP's structures. In the year 1949 they were ascribed to the adequate levels of Centres for Party Propaganda. There were 25 such libraries operating in Warsaw Voivodship. According to preserved documents these libraries brought a rather small contribution to upgrading the readership level neither of local party activist nor of ordinary party members. It might be argued that the aversion against libraries and reading, specifically on the commune and district levels, derived from low readership level of the party activists could have transformed onto functioning of party and public libraries. The attitude of local party activists caused many ostensible activities of authorities in the field of reading development.

Key words: Libraries of Polish Workers Party 1945-1949 - libraries of Polish United Workers' Party 1949-1954 - reading habits - Stalinism - Warsaw Voivodship. 
